\title{
CORRIGENDUM
}

\section{Comparison of the effects of cassava (Manihot esculenta Crantz) organic cyanide and inorganic cyanide on muscle and bone development in a Nigerian breed of dog}

\author{
BY C. IBEBUNJO, BERYL P. KAMALU AND E. C. IHEMELANDU
}

Vol. 68 (1992), no. 2

Page 485, Table 2

For Statistical significance of difference: $P<$

Read Statistical significance of difference: $P>$

\section{NUTRITION RESEARCH REVIEWS}

Members of the Nutrition Society and other readers of the British Journal of Nutrition are invited to suggest topics and authors for reviews in any field of nutrition research. Contributions from authors overseas who write clear concise English will be particularly welcome. Reviews should give critical assessment of the literature and advance new concepts rather than merely catalogue past findings. Proposals, accompanied by a clear statement of why the proposer thinks that the chosen topic and author(s) are particularly appropriate, should be sent to: Professor M. I. Gurr, Vale View Cottage, Maypole, St Mary's, Isles of Scilly, TR21 0NU. 